\title{
Pertumbuhan dan produksi selada (Lactuca sativa l.) pada pemberian berbagai jenis pupuk organik
}

\author{
(Growth and production of lettuce (Lactuca sativa l.) On the granting of various organic \\ fertilizers)
}

\author{
S. V. Asprillia, A. Darmawati, dan W. Slamet \\ Agroecotechnology, Faculty of Animal and Agricultural Sciences, Diponegoro University \\ Tembalang Campus, Semarang 50275 - Indonesia \\ Coresponding E-mail: sarahvandaa@gmail.com
}

\begin{abstract}
The aimed of the research was to analyze the effect the organic fertilizer to increase growth and production of lettuce (Lactuca sativa L.). The Research was conducted on April - July 2017 at Taburmas Garden, Mpu Tantular street, No. 10-12 Bandungan, Semarang. The research design was Completely Randomized Design with 7 treatments and 3 replications so that there were 21 units of experiment. The research used organic fertilizer $100 \mathrm{~kg} \mathrm{~N} / \mathrm{ha}$. The treatment were; T0: no organic fertilizer, $\mathrm{T} 1$ : cow manure $(1.15 \mathrm{~kg} / \mathrm{plot}), \mathrm{T} 2$ : goat manure $(1.16 \mathrm{~kg} / \mathrm{plot}), \mathrm{T} 3$ : litter compost $(1.5 \mathrm{~kg} / \mathrm{plot}), \mathrm{T} 4$ : fertilizer guano $(0.226 \mathrm{~kg} / \mathrm{plot}), \mathrm{T} 5$ : chicken manure $(1,176 \mathrm{~kg} / \mathrm{plot})$, T6: rabbit manure $(0.763 \mathrm{~kg} / \mathrm{plot})$. Data were subjected to Analysis of variance (ANOVA) and continued by Duncan's Multiple Range Test (DMRT) at $\alpha=5 \%$. The results of this study showed that the use of organic fertilizer increased the growth and production of lettuce. Guano ferlitizer and chicken manure fertilizers resulted the highest growth and production in lettuce plants.
\end{abstract}

Keywords : lettuce, organic fertilizer.

\begin{abstract}
ABSTRAK
Penelitian bertujuan untuk mengkaji pengaruh pemberian berbagai jenis pupuk organik terhadap peningkatan pertumbuhan dan produksi selada (Lactuca sativa L.). Penelitian dilaksanakan pada bulan April - Juli 2017 di Kebun Taburmas Farm, yang terletak di Jl. Mpu Tantular, No. 10-12 Bandungan, Semarang, Jawa Tengah. Penelitian ini menggunakan Rancangan Acak Lengkap (RAL) monofaktor dengan 7 taraf perlakuan dan 3 ulangan sehingga terdapat 21 unit percobaan. Perlakuan yang diberikan dengan pupuk organik setara dengan $100 \mathrm{~kg} \mathrm{~N} / \mathrm{ha}$. Pupuk organik yang digunakan yaitu T0: tanpa pupuk organik, T1: pupuk kandang sapi $(1,15 \mathrm{~kg} /$ petak), T2: pupuk kandang kambing $(1,16 \mathrm{~kg} /$ petak), T3: pupuk kompos seresah $(1,5 \mathrm{~kg} /$ petak $), \mathrm{T} 4$ : pupuk guano $(0,226 \mathrm{~kg} /$ petak $), \mathrm{T} 5$ : pupuk kandang ayam $(1,176 \mathrm{~kg} /$ petak $), \mathrm{T} 6$ : pupuk kandang kelinci $(0,763 \mathrm{~kg} /$ petak). Data hasil penelitian diolah dengan menggunakan metode analisis of varians (ANOVA) dan apabila terdapat pengaruh nyata maka dilanjutkan maka dilanjutkan dengan uji wilayah Duncan's Multiple Range Test (DMRT) taraf signifikasi $5 \%$. Hasil penelitian ini menunjukkan bahwa penggunaan pupuk organik meningkatkan pertumbuhan dan produksi selada. Penggunaan pupuk guano dan pupuk kandang ayam memberikan pertumbuhan dan produksi tertinggi pada tanaman selada.

Kata Kunci: selada, pupuk organik.
\end{abstract}

\section{PENDAHULUAN}

Selada merupakan tanaman sayuran yang berumur pendek dan termasuk dalam famili
Compositae. Tanaman selada dapat tumbuh di dataran rendah maupun pada dataran tinggi. Pertumbuhan yang optimal bagi selada yaitu pada lahan yang subur dengan mengandung banyak 
humus, pasir ataupun lumpur dengan $\mathrm{pH}$ tanah 56,5.Tanaman selada (Lactuca sativa L.) merupakan salah satu tanaman sayuran yang termasuk dalam famili Compositae (Sunarjono, 2014). Daun selada memiliki bentuk, ukuran dan warna yang beragam tergantung varietasnya. Tinggi tanaman selada daun berkisar antara 30-40 $\mathrm{cm}$ dan tinggi tanaman selada berkisar antara 20$30 \mathrm{~cm}$. Selada memiliki sistem perakaran tunggang dan serabut. Akar serabut menempel pada batang dan tumbuh menyebar ke semua arah pada kedalaman 20-50 $\mathrm{cm}$ atau lebih (Novriani, 2014). Tanaman selada dapat dibudidayakan di daerah penanaman yang memliki ketinggian 1.000-1.900 meter diatas permukaan laut (mdpl). Suhu yang cocok untuk budidaya selada adalah $15-25^{\circ} \mathrm{C}$. Suhu yang lebih tinggi dari $30^{\circ} \mathrm{C}$ dapat menghambat pertumbuhan, merangsang tumbuhnya tangkai bunga (bolting), dan dapat menyebabkan rasa pahit. Curah hujan yang optimal untuk pertumbuhan tanaman selada adalah $1.000-1.500 \mathrm{~mm} /$ tahun, Kelembaban yang sesuai untuk pertumbuhan selada yaitu berkisar antara $80-90 \%$.

Budidaya tanaman selada dengan pupuk organik biasanya dilakukan oleh petani dengan memanfaatkan pupuk kandang (pukan) yang dapat menambah unsur hara tanah dan memperbaiki sifat fisik tanah. Pupuk organik merupakan pupuk yang berasal dari sisa-sisa tanaman serta hewan atau manusia, misalnya saja seperti pupuk kandang (pukan), pupuk hijau, dan kompos baik yang berbentuk cair maupun padat. Pengaruh pengaplikasian pupuk organik pada tanaman salah satunya yaitu dapat meningkatkan aktifitas mikroorganisme, sehingga kegiatan organisme dalam menguraikan bahan organik dapat meningkatkan unsur hara dalam tanah dan menjadi tersedia bagi tanaman (Makaruku, 2015).

Pukan sapi mengandung bahan organik yang berperan penting dalam memperbaiki sifat fisika tanah, kimia tanah, dan biologi tanah. Pupuk ini terdiri dari $44 \%$ bahan padat dan $63 \%$ bahan cair. Penggunaan pukan kambing dalam budidaya tanaman selada dapat berfungsi memperbaiki aerasi tanah, menambah kemampuan tanah menahan unsur hara, meningkatkan kapasitas menahan air, meningkatkan daya sangga tanah, serta berperan sebagai sumber energi bagi mikroorganisme tanah dan sebagai sumber unsur hara. Pupuk kompos yang terdapat dalam tanah dapat merangsang pertumbuhan tanaman (Adil, 2006). Pupuk guano tidak hanya dapat merangsang pertumbuhan dengan baik, namun guano juga dapat tahan lama tinggal di dalam jaringan tanah, dapat meningkatkan produktifitas tanah dan juga menyediakan nutrisi bagi tanaman dalam jumlah yang lebih banyak dari pada pupuk kimia buatan (Grantina et al., 2015). Pukan ayam memiliki kandungan $\mathrm{N}$, $\mathrm{P}$, dan $\mathrm{K}$ yang paling tinggi dibandingan pukan yang lain. Pukan ayam lebih cepat tersedianya dibandingkan pupuk kandang jenis lain, serta merupakan pukan dengan unsur hara terkaya (Sari et al., 2016). Tingginya protein pada kotoran kelinci disebabkan populasi mikroba dalam sekum yang sangat aktif dalam memanfaatkan nitrogen dari urea darah yang masuk sekum dan protein sehingga kadar nitrogen dan fosfor dalam kotoran kelinci lebih tinggi dibandingkan ternak ruminansia tetapi lebih rendah dari guano.

Tujuan dari penelitian ini yaitu untuk untuk mengkaji pengaruh pemberian berbagai jenis pupuk organik terhadap peningkatan pertumbuhan dan produksi selada (Lactuca sativa L.).

\section{MATERI DAN METODE}

\section{Materi}

Penelitian dilaksanakan pada bulan April-Juli 2017 di Kebun Tabur Mas Farm, Bandungan, di Jl. Mpu Tantular, No. 10-12, Bandungan, Semarang, Jawa Tengah. Peralatan yang digunakan dalam penelitian ini adalah meteran, cangkul, selang, timbangan analitik, kamera, tali rafia, kantong sampel, leaf area meter, spektrofotometer, alat tulis dan label. Bahan yang digunakan dalam penelitian yaitu benih selada (Lactuca sativa L.), air, lahan, pupuk kandang (pukan) sapi, pukan kambing, pupuk kompos seresah, pupuk guano, pukan ayam, dan pukan kelinci.

\section{Metode}

Penelitian ini menggunakan Rancangan Acak Lengkap (RAL) monofaktor dengan 7 taraf perlakuan dan 3 ulangan sehingga terdapat 21 unit percobaan. Perlakuan yang diberikan dengan pupuk organik setara dengan $100 \mathrm{~kg} \mathrm{~N} / \mathrm{ha}$. Pupuk organik yang digunakan yaitu $\mathrm{T} 0$ : tanpa pupuk 
organik, T1: pukan sapi (1,15 kg/petak), T2: pukan kambing (1,16 kg/petak), T3: pupuk kompos seresah (1,5 kg/petak), T4: pupuk guano $(0,226 \mathrm{~kg} /$ petak $), \quad \mathrm{T} 5:$ pukan ayam $(1,176$ $\mathrm{kg} /$ petak), T6: pukan kelinci (0,763 kg/petak).

Pemupukan dengan dosis setara dengan 100 N/ha. Pemberian perlakuan pupuk yaitu T0: tanpa pupuk organik, T1: pukan sapi $(1,15 \mathrm{~kg} /$ petak $)$, T2: pukan kambing (1,16 kg/petak), T3: pupuk kompos seresah (1,5 kg/petak), T4: pupuk guano $(0,226 \mathrm{~kg} /$ petak $), \quad \mathrm{T} 5:$ pukan ayam $(1,176$ $\mathrm{kg} /$ petak), T6: pukan kelinci $(0,763 \mathrm{~kg} /$ petak). Parameter yang diamati adalah tinggi tanaman, jumlah daun, lebar tajuk, berat segar tajuk per petak, berat segar akar per petak, berat segar tajuk per tanaman, berat segar akar per tanaman, dan luas daun. Data hasil penelitian diolah dengan menggunakan metode analisis of varians (ANOVA) dan apabila terdapat pengaruh nyata maka dilanjutkan maka dilanjutkan dengan uji wilayah berganda Duncan's Multiple Range Test (DMRT) taraf signifikasi 5\%.

\section{HASIL DAN PEMBAHASAN}

\section{Pertumbuhan Tanaman Selada Pada Berbagai Pupuk Organik}

Hasil analisis tanah dan pupuk organik yang digunakan dalam penelitian tersaji pada Tabel 1 .

Tanah merupakan salah satu media tumbuh tanaman yang dapat mempengaruhi pertumbuhan dan produksi tanaman untuk mendapatkan hasil yang optimal. Bahan organik tidak dapat langsung dimanfaatkan oleh tanaman apabila perbandingan antara $\mathrm{C} / \mathrm{N}$ ratio dalam tanah tersebut relatif tinggi, namun bila $\mathrm{C} / \mathrm{N}$ ratio rendah maka bahan tersebut dapat diaplikasikan langsung ke tanah dan unsur hara yang terkandung dapat diserap oleh tanaman (Gunawan, 2015). Menurut (Arinong, 2014) bahwa suatu tanaman akan tumbuh dan mencapai tingkat produksi tinggi bila unsur hara yang dibutuhkan tanaman berada dalam keadaan cukup tersedia dan berimbang dalam tanah dan unsur N,P, K merupakan unsur hara yang mutlak diperlukan tanaman, apabila salah satu unsur hara tersebut kurang atau tidak tersedia dalam tanah, akan mempengaruhi pertumbuhan dan produksi tanaman selada.

Hasil analisis ragam menunjukan bahwa perbedaan perlakuan jenis pupuk organik berpengaruh nyata $(\mathrm{p}<0,05)$ pada parameter tinggi tanaman, jumlah daun dan lebar tajuk tanaman selada. Pertumbuhan tanaman selada pada pemberian berbagai pupuk organik tersaji pada Tabel 2.

Hasil uji lanjut dengan (DMRT) menunjukan bahwa tinggi tanaman pada perlakuan pukan ayam (T5) memberikan hasil rerata sebesar $8,42 \mathrm{~cm}$ yang nyata lebih tinggi apabila dibandingkan dengan perlakuan tanpa pupuk organik (T0), pukan sapi (T1) serta pupuk seresah daun (T3).

Tabel 1. Hasil Analisis Tanah dan Pupuk Organik

\begin{tabular}{lccccc}
\hline \hline \multirow{2}{*}{ Sampel } & \multicolumn{3}{c}{ Kandungan } & \multirow{2}{*}{ Rasio } \\
\cline { 2 - 4 } & $\mathrm{N}(\%)$ & $\mathrm{P}_{2} \mathrm{O}_{5}(\%)$ & $\mathrm{K}_{2} \mathrm{O}(\%)$ & $\mathrm{C} / \mathrm{N}$ \\
\hline Tanah & 0,36 & 0,86 & 0,03 & 4,24 & 11,77 \\
Pupuk Kandang Sapi & 1,74 & 0,66 & 1,08 & 11,43 & 6,57 \\
Pupuk Kandang Kambing & 1,72 & 0,32 & 1,12 & 10,93 & 6,35 \\
Pupuk Kompos Serasah Daun & 1,32 & 0,18 & 0,85 & 11,51 & 8,72 \\
Pupuk Guano & 8,82 & 0,51 & 0,88 & 21,95 & 2,49 \\
Pupuk Kandang Ayam & 1,84 & 1,03 & 0,45 & 22,20 & 12,06 \\
Pupuk Kandang Kelinci & 1,1 & 0,82 & 0,04 & 12,23 & 11,11 \\
\hline
\end{tabular}

Keterangan : Superskrip yang berbeda $(\mathrm{p}>0,05)$ pada kolom dan baris yang sama menunjukkan perbedaan yang nyata 
Tabel 2. Pertumbuhan Tanaman Selada Pada Berbagai Pupuk Organik

\begin{tabular}{lccc}
\hline \hline \multicolumn{1}{c}{ Parameter } & Tinggi Tanaman & Jumlah Daun & Lebar Tajuk \\
\hline \multicolumn{1}{c}{ Perlakuan } & $------c m------$ & ----- helai------ & $-------c m-------$ \\
\hline Tanpa Pupuk Organik (T0) & $4,05^{\mathrm{c}}$ & $2,67^{\mathrm{c}}$ & $4,31^{\mathrm{d}}$ \\
Pukan Sapi (T1) & $6,29^{\mathrm{b}}$ & $3,33^{\mathrm{b}}$ & $6,62^{\mathrm{bcd}}$ \\
Pukan Kambing (T2) & $7,52^{\mathrm{ab}}$ & $3,87^{\mathrm{ab}}$ & $8,41^{\mathrm{bcc}}$ \\
Pupuk Seresah Daun (T3) & $6,35^{\mathrm{b}}$ & $3,31^{\mathrm{bc}}$ & $6,02^{\mathrm{cd}}$ \\
Pupuk Guano (T4) & $7,55^{\mathrm{ab}}$ & $4,24^{\mathrm{a}}$ & $11,33^{\mathrm{a}}$ \\
Pukan Ayam (T5) & $8,42^{\mathrm{a}}$ & $4,23^{\mathrm{a}}$ & $10,07^{\mathrm{ab}}$ \\
Pukan Kelinci (T6) & $7,74^{\mathrm{a}}$ & $4,12^{\mathrm{ab}}$ & $8,90^{\mathrm{abc}}$ \\
\hline
\end{tabular}

Keterangan : Superskrip yang berbeda $(p>0,05)$ pada kolom dan baris yang sama menunjukkan perbedaan yang nyata

Akan tetapi, tidak berbeda nyata dengan perlakuan pukan kambing (T2), pupuk guano (T4) serta pukan kelinci (T6). Hal ini menunjukan bahwa pemberian perlakuan pupuk kandang ayam dapat memberikan pengaruh nyata bagi pertumbuhan vegetatif tanaman selada terutama pada pertumbuhan bagian batang. Pukan ayam relatif lebih cepat terdekomposisi serta memiliki kandungan hara yang lebih lengkap dibandingkan dengan pupuk kandang lainnya sehingga dapat memberikan respon tanaman yang terbaik. Hal ini diperkuat oleh Sutedjo et al. (2002) yang menyatakan bahwa pupuk kandang ayam dianggap sebagai pupuk yang lengkap karena selain tersedianya unsur hara bagi tanaman juga dapat mengembangkan mikroorganisme di dalam tanah sehingga dapat membantu struktur tanah. Menurut Ningsih (2012) bahwa adanya pengaruh yang nyata terhadap tinggi tanaman karena pukan ayam mengandung unsur hara yang lengkap untuk menggemburkan tanah dan memperbaiki struktur tanah yang dapat menaikkan daya serap air sehingga kebutuhan tanaman tercukupi sehingga dapat menambah tinggi tanaman.

Hasil uji lanjut dengan (DMRT) menunjukan bahwa perlakuan pupuk guano (T4) pada parameter jumlah daun dan lebar tajuk tanaman selada memberikan rerata yang nyata lebih tinggi yaitu jumlah daun 4,24 helai dan lebar tajuk tanaman sebesar $11,33 \mathrm{~cm}$, dan berbeda nyata dengan perlakuan tanpa pupuk (T0), pukan sapi (T1), dan pupuk seresah daun (T3). Akan tetapi pada parameter jumlah daun dan lebar tajuk tanaman tidak berbeda nyata dengan perlakuan pukan kambing (T2), pukan ayam (T5) dan pukan kelinci (T6).

Jumlah daun dan lebar tajuk tanaman selada pada perlakuan pupuk guano menghasilkan rerata tertinggi hal ini disebabkan karena pupuk guano memiliki kandungan unsur hara nitrogen $(\mathrm{N})$ yang tinggi namun memiliki kandungan $\mathrm{C} / \mathrm{N}$ yang tergolong rendah yang dapat mendorong proses pertumbuhan tanaman selada. Hal ini sesuai dengan pendapat Hanafiah (2007) yang menyatakan bahwa kandungan nitrogen, Corganik dan kadar $\mathrm{P}$ pada kotoran kelelawar terasuk dalam kategori sangat tinggi, namun kadar $\mathrm{K}$ sedang dan memiliki ratio $\mathrm{C} / \mathrm{N}$ yang sangat rendah. Hal yang sama dikemukakan oleh (Lingga, 2007) yang menyatakan bahwa pada saat pupuk guano mengalami proses dekomposisi maka nitrogen dibebaskan dalam bentuk kation $\mathrm{NH} 4+$ (amonium), kecepatan proses ini tergantung pada ratio antara unsur karbon-nitrogen $(\mathrm{C} / \mathrm{N})$ apabila $\mathrm{C} / \mathrm{N}$ rendah maka proses perombakan akan berjaan lebih cepat, bentuk ion $\mathrm{NH}+$ yang dibebaskan dapat secara langsung diserap oleh tanaman dan dimanfaatkan oleh mikroorganisme tanah atau diubah mejadi anion NO-3 (nitrat) sehingga di dalam tanah ditemukan nitrogen berbentuk nitrat lebih banyak dibandingkan dengan bentuk amonium yang pada umumnya tanaman lebih banyak menyerap nitrogen dalam bentuk nitrat untuk proses pertumbuhan . 


\section{Produksi Tanaman Selada}

Hasil analisis ragam menunjukan bahwa perbedaan perlakuan jenis pupuk organik berpengaruh nyata $(p<0,05)$ pada parameter berat segar tajuk per petak, berat segar akar per petak, berat segar tajuk per tanaman, berat segar akar per tanaman, dan luas daun tanaman selada. Produksi tanaman selada pada pemberian berbagai pupuk organik tersaji pada Tabel 3. bahwa pada perlakuan pupuk guano (T4) memberikan hasil rerata tertinggi sebesar $2,32 \mathrm{~cm}$. Perlakuan pupuk guano (T4) pada parameter luas daun tersebut tidak berbeda nyata dengan perlakuan pukan ayam (T5), akan tetapi berbeda nyata dengan perlakuan tanpa pupuk (T0), pukan sapi (T1), pukan kambing (T2), pupuk seresah daun (T3), dan pukan kelinci (T6). Hal tersebut disebabkan daun merupakan organ penting tanaman yang berperan dalam proses fotosintesis.

Tabel 3. Produksi Tanaman Selada Pada Berbagai Pupuk Organik

\begin{tabular}{|c|c|c|c|c|c|}
\hline Parameter & $\begin{array}{c}\text { Berat } \\
\text { Segar } \\
\text { Tajuk Per } \\
\text { Petak }\end{array}$ & $\begin{array}{l}\text { Berat Segar } \\
\text { Akar Per } \\
\text { Petak }\end{array}$ & $\begin{array}{c}\text { Berat Segar } \\
\text { Tajuk Per } \\
\text { Tanaman }\end{array}$ & $\begin{array}{c}\text { Berat Segar } \\
\text { Akar Per } \\
\text { Tanaman }\end{array}$ & $\begin{array}{l}\text { Luas } \\
\text { Daun }\end{array}$ \\
\hline Perlakuan & -----kg---- & ----kg---- & ------gr----- & ------gr----- & $--\mathrm{cm}--$ \\
\hline Tanpa Pupuk Organik (T0) & $0,080^{\mathrm{c}}$ & $0,006^{\mathrm{e}}$ & $1,99^{\mathrm{c}}$ & $0,15^{\mathrm{e}}$ & $1,34^{\mathrm{b}}$ \\
\hline Pukan Sapi (T1) & $0,337^{\mathrm{c}}$ & $0,033^{\text {cd }}$ & $8,41^{\mathrm{c}}$ & $0,81^{\text {cd }}$ & $1,45^{\mathrm{b}}$ \\
\hline Pukan Kambing (T2) & $0,961^{\mathrm{b}}$ & $0,042^{\mathrm{bc}}$ & $24,03^{\mathrm{b}}$ & $1,04^{\mathrm{bc}}$ & $1,56^{\mathrm{b}}$ \\
\hline Pupuk Seresah Daun (T3) & $0,363^{\mathrm{c}}$ & $0,020^{\mathrm{de}}$ & $9,08^{\mathrm{c}}$ & $0,49^{\mathrm{de}}$ & $1,33^{\mathrm{b}}$ \\
\hline Pupuk Guano (T4) & $1,513^{\mathrm{a}}$ & $0,069^{\mathrm{a}}$ & $37,82^{\mathrm{a}}$ & $1,72^{\mathrm{a}}$ & $2,32^{\mathrm{a}}$ \\
\hline Pukan Ayam (T5) & $1,499^{\mathrm{a}}$ & $0,055^{\mathrm{ab}}$ & $37,48^{\mathrm{a}}$ & $1,39^{\mathrm{ab}}$ & $1,87^{\mathrm{ab}}$ \\
\hline Pukan Kelinci (T6) & $1,495^{\mathrm{a}}$ & $0,057^{\mathrm{ab}}$ & $37,38^{\mathrm{a}}$ & $1,42^{\mathrm{ab}}$ & $1,64^{\mathrm{b}}$ \\
\hline
\end{tabular}

Keterangan : Superskrip yang berbeda $(\mathrm{p}>0,05)$ pada kolom dan baris yang sama menunjukkan perbedaan yang nyata

Hasil uji lanjut dengan (DMRT) menunjukan bahwa parameter produksi selada (berat segar tajuk per petak, berat segar akar per petak, berat segar tajuk per tanaman, dan berat segar akar per tanaman) mempunyai nilai tertinggi pada perlakuan pupuk guano (T4) dibandingkan dengan perlakuan lain masing-masing sebesar berat segar tajuk per petak yaitu $1,513 \mathrm{~kg}$, berat segar akar per petak yaitu $0,069 \mathrm{~kg}$, berat segar tajuk per tanaman yaitu 37,82 gr, berat segar akar per petak yaitu 1,72 gr. Perlakuan pupuk guano (T4) pada parameter berat segar tajuk per petak, berat segar akar per petak, berat segar tajuk per tanaman, berat segar akar per tanaman tersebut tidak berbeda nyata dengan perlakuan pukan ayam (T5) dan pukan kelinci (T6), akan tetapi berbeda nyata dengan perlakuan tanpa pupuk (T0), pukan sapi (T1), pukan kambing (T2) dan pupuk seresah daun (T3).

Parameter luas daun tanaman menunjukan
Proses fotosintesis diperlukan aerasi yang baik pada media tanam agar dapat mendukung akar tanaman dalam menyerap air dan unsur hara secara optimal yang selanjutnya ditranslokasikan tanaman untuk proses metabolisme yang berperan dalam pertambahan luas daun (Sukawati, 2010).

Perlakuan pupuk guano memberikan hasil rerata tertinggi pada parameter berat segar tajuk per petak, berat segar akar per petak, berat segar tajuk per tanaman, berat segar akar per tanaman, dan luas daun tanaman selada. Tajuk tanaman selada terdiri atas batang dan daun, semakin banyak jumlah daun maka berat segar tajuk tanaman juga akan meningkat (Fahrudin, 2009). Semakin banyak jumlah daun makan semakin berat tanaman yang dikonsumsi akan meningkat. Meningkatnya berat tanaman yang dikonsumsi dikarenakan panjang daun dan klorofil, semakin panjang daun maka semakin banyak pula jumlah klorofil yang dapat memperlancar fotosintesis 
sehingga meningkatkan cadangan makanan untuk disimpan dan dapat mempengaruhi berat tanaman yang dikonsumsi. Daun merupakan organ penting tanaman yang berperan dalam proses fotosintesis. Proses fotosintesis diperlukan aerasi yang baik pada media tanam agar dapat mendukung akar tanaman dalam menyerap air dan unsur hara secara optimal yang selanjutnya ditranslokasikan tanaman untuk proses metabolisme yang berperan dalam pertambahan luas daun (Nurrohman et al., 2014). Selain itu, pupuk guano juga memiliki kandungan $\mathrm{C} / \mathrm{N}$ ratio yang terendah, apabila $\mathrm{C} / \mathrm{N}$ ratio rendah maka unsur makro dan mikro dalam pupuk dapat diserap tanaman untuk memperoleh hara yang digunakan pada proses pertumbuhan, seperti halnya pada Tabel 2 (pertumbuhan tanaman selada) bahwa pemberian pupuk guano mampu memberikan hasil rerata jumlah daun dan lebar tajuk tanaman selada yang paling tinggi, yang nantinya akan berpengaruh pula terhadap produksi tanaman selada. Djafar et al. (2013) menyatakan bahwa ada hubungan yang kuat antara kadar $\mathrm{N}$ total yang pengaruhnya pada produksi dan pertumbuhan tanaman selada. Menurut Safitry (2013) bahwa nilai rasio C/N yang terlalu tinggi tidak cocok untuk produksi tanaman.

\section{KESIMPULAN}

Kesimpulan dari hasil penelitian adalah penggunaan pupuk organik meningkatkan pertumbuhan dan produksi selada. Penggunaan pupuk guano dan pupuk kandang ayam memberikan pertumbuhan dan produksi tertinggi pada tanaman selada.

\section{DAFTAR PUSTAKA}

Adil, W. H., N. Sunarlim, dan I. Roostika. 2006. Pengaruh tiga jenis pupuk nitrogen terhadap tanaman sayuran. J. Biodiversitas. 7(1): 7780.

Arinong, A. R., Vandalisna., dan Asni. 2014. Pertumbuhan dan produksi tanaman sawi (Brassica juncea L.) dengan pemberian mikroorganisme lokal (mol) dan pupuk kandang ayam. J. Agrisistem. 10(1): 40-46.
Djafar, T. A., A. Barus., dan Syukri. 2013. Pespon pertumbuhan dan produksi sawi (Brassica juncea L.) terhadap pemberian urine kelinci dan pupuk guano. J. Agroekoteknologi. 1(3): 647-654.

Fahrudin, F. 2009. Budidaya caisim (Brassica juncea L.) menggunakan ekstrak teh dan pupuk kascing. Skripsi. Fakults Pertanian. Universitas Sebelas Maret, Surakarta. (Tidak dipublikasikan).

Grantina, L., Levina, and G. Levinsh. 2015. Microbiological Characteristics And Effect On Plants Of The Organic Fertilizer From Vermicompost And Bat Guano. J. Researh For Rural Development. 1: 95-101.

Gunawan, R., R. Kusmiadi., dan E. Prasetiyono. 2015. Studi pemanfaatan sampah organik sayuran sawi (Brassica juncea L.) dan limbah rajungan (Potunus pelagicus) untuk pembuatan kompos organik cair. J. Pertanian dan Lingkungan. 8(1): 37-47.

Hanafiah, K. A. 2007. Dasar - Dasar Ilmu Tanah. PT Raja Grafindo Persada. Jakarta.

Lingga, P.. 2007. Petunjuk Penggunaan Pupuk. Penebar Swadaya. Depok.

Ningsih, S. 2012 Pengaruh pemberian pupuk kandang ayam dan pupuk N (ZA) terhadap pertumbuhan sera produksi tanaman sawi (Brassica chinensis L.). 9(1): 1-6.

Makaruku, M. H. 2015. Respon pertumbuhan dan produksi tanaman selada (Lactuca sativa $\mathrm{L}$.) terhadap permberian pupuk organik.J. Agroforestri. 10(3): 241-246.

Novriani. 2014. Respon Tanaman Selada (Lactuca sativa L.) Terhadap pemberian pupuk organik cair asal sampah organik pasar. J. Klorofil. 9(2):57-61.

Nurrohman, M., A. Suryanto dan K. W. Puji. 2014. Penggunaan fermentasi ekstrak paitan (Tithonia diversifolia L.) dan kotoran kelinci cair sebagai sumber hara pada 
budidaya sawi (Brassica juncea L.) secara hidroponik rakit apung. J. Produksi Tanaman. 2(8): 649-657.

Safitry, M. R., dan J. G. Kartika. 2013. Pertumbuhan dan produks bunic tegak (Phaseolus vulgaris L.) pada beberapa kombinasi media tanam organik. Buletin Agrohorti. 1(1): 94-103.

Sari, K. M., A. Pasigat dan I. Wahyudi. 2016. Pengaruh pupuk kandang ayam terhadap pertumbuhan dan hasil tanaman kubis bunga (Brassica oleracea Var. Bathytis L.) on oxic dystrudepts lembantongoa. J. Agrotekbos. 4(2): 151-159.

Sukawati, I. 2010. Pengaruh kepekatan larutan nutrisi organik terhadap pertumbuhan dan hasil baby kailan(Brassica oleraceae Var. Albo-glabra) pada berbagai komposisi media tanam dengan sistem hidroponik substrat. Skrispsi. Fakultas Pertanian. Universitas Sebelas Maret. Surakarta. (Tidak dipublikasikan).

Sumpena, U. dan I. Meilani. 2005. Pengaruh pupuk organik cascing dan jarak tanam terhadap pertumbuhan dan hasil wortel (Daucus carota L.). J. Agrivigor. 5(1): 2633.

Sunarjono, H. 2014. Bertanam 30 Jenis Sayur. Penebar Swadaya. Jakarta.

Sutedjo, M. M. dan A. G. Kartasapoetra. 2002. Pengantar Ilmu Tanah. Bina Aksara, Jakarta. 